\title{
Ways of licensing Hungarian external possessors*
}

\section{Introduction}

This paper examines the status of Hungarian dative marked noun phrases interpreted as external possessors of a sister constituent. It challenges the widely accepted view put forth by Szabolcsi $(1983,1992$, etc.) that external possessors are uniformly assigned a theta role by the possessum, and they are uniformly raised from its maximal projection via A-bar movement. It argues instead that external possessors can also be base-generated outside the projection of the possessum, binding its internal possessor, and can receive an 'affected' theta role from the verb. The paper distinguishes three different types of external possession, showing that they have different licensing conditions, and different agreement properties. The agreement properties are related to the base-generation versus movement derivation of the external possessor. Since speakers display some variation in the choice of agreement, the analyses will be based on the distribution of the grammaticality judgments of 40 native speakers.

The paper is organized as follows: section 2 presents the standard view on Hungarian external possessors. Section 3 summarizes the basic information about external possessors across languages. Sections 4, 5, and 6 introduce the three major types of Hungarian external possessors: those licensed as affected arguments of the matrix predicate, those externalized via topicalization, focusing, or quantifier raising, and those externalized owing to the semantic incorporation of the possessum into the verbal predicate. Section 7 is a summary.

\section{The standard view on Hungarian external possessors}

Szabolcsi argued in a series of seminal studies (Szabolcsi 1983, 1992, 1994, etc.) that nak/nek marked constituents that appear to be coarguments of a constituent bearing possessive inflection are, in fact, extracted possessors. Such external possessors are generated and thetamarked in the maximal projection of the possessum, in the specifier of $(\mathrm{N}+\mathrm{I}) \mathrm{P}$, where they are assigned nominative case by possessive inflection. ${ }^{1}$ They are externalized by A-bar movement through Spec,DP, where they receive a -nak/nek suffix, as shown in (1). This -nak/nek suffix, though homophonous with the morphological marker of the dative case, is claimed not to be a

\footnotetext{
*This paper was written with the support of grant 100804 of OTKA, the Hungarian National Science Foundation. I also owe thanks to Anna Szabolcsi and two anonymous reviewers for for their useful comments.

${ }^{1}$ I stands for possessive inflection, comprising a possession morpheme and agreement.
} 
case ending but to mark the operator status of the A-bar moved possessor. Spec,DP, whose function is analogous to that of Spec, CP, serves as an escape hatch for the possessor, as shown in $(1 \mathrm{a}, \mathrm{b})$. Possessor extraction yields constructions like those in $(2 \mathrm{a}, \mathrm{b})$.

(1)

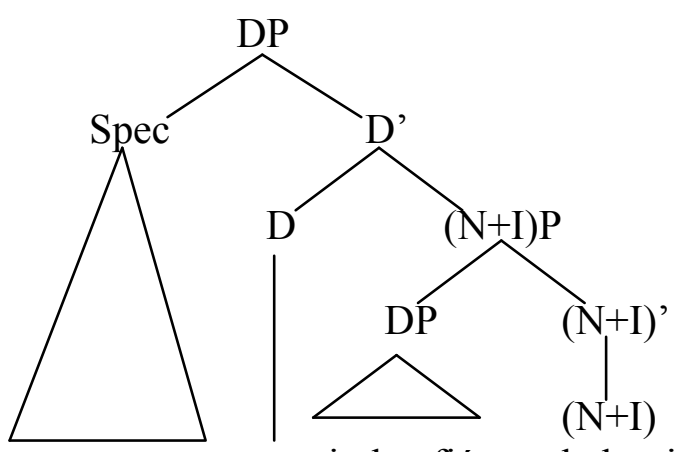

a.

minden fiú kalap-ja every boy.NOM hat-3SG

b. minden fiú-nak $\mathrm{k}_{\mathrm{i}}$ a $t_{\mathrm{i}} \quad$ kalap-ja every boy-DAT the hat-3SG

'every boy's hat'

(2)a. Minden fiú-nak $\mathrm{i}_{\mathrm{i}}$ elveszett [DP $t_{\mathrm{i}}$ a [(N+Poss)P $t_{\mathrm{i}}$ kalap-ja $\left.]\right]$ every boy-DAT got.lost the hat-3SG 'Every boy's hat got lost.'

b. Minden fiú-nak $k_{\mathrm{i}}$ van [DP $t_{\mathrm{i}}\left[(\mathrm{N}+\mathrm{Poss}) \mathrm{P} t_{\mathrm{i}}\right.$ kalap-ja] $]$ every boy-DAT is hat-3SG

'Every boy has a hat.'

According to traditional grammars (e.g., Tompa 1961-62), sentences like (2a,b) involve a predicate with two arguments. Szabolcsi refuted this approach on the basis of two kinds of evidence. First, the predicates of (2a,b), meaning 'get lost' and 'be', only assign a 'theme' theta role, hence they cannot be the theta role assigners of the -nak/nek marked argument, as well. Furthermore, the -nak/nek marked argument agrees with the nominative marked theme; however, coarguments never agree; agreement is a relation between a head and its specifier. As Szabolcsi observed, the externalization of the possessor is obligatory in existential sentences of type (2b). The reason is that the verb be selects a non-specific indefinite argument to be semantically incorporated into the verb. A possessive construction containing an internal possessor is always definite; however, a possessum associated with an external 
possessor can be non-specific indefinite. (For a modified version of this theory, see Alberti (1995).)

Den Dikken (1999) and É. Kiss (2000) challenged Szabolcsi’s claim that -nak/nek marked external possessors are in the nominative case, and their -nak/nek suffix is assigned by $\mathrm{D}$ to mark their operator role. According to den Dikken, the possessor is the complement of a dative preposition in the structure underlying possessive constructions across languages. É. Kiss (2000) also claimed that the case assigned to the possessor complement of a possessum is the dative; possessors apparently in the nominative case are caseless possessors in modifier/specifier position. The dative possessor originates as a complement of $\mathrm{N}+\mathrm{Poss}$, and it lands in a DP-adjoined position. It cannot land in Spec,DP because Spec,DP is reserved for the demonstrative determiner (cf. Kenesei 1994), as is shown by the example in (3). That the dative constituent preceding the demonstrative in (3) is part of the projection of the possessum is shown by the fact that the slot enclosed by the focus particle csak 'only' and the verb can contain a single, focussed constituent.

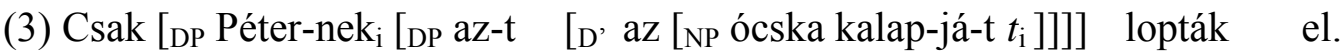
only Peter-DAT that-ACC the old hat-POSS-ACC stole.3PL PRT 'Only that old hat of Peter's was stolen.'

Szabolcsi (1983, 1992) assumed, following Melcsuk (1965), that possessive inflection is a complex morpheme consisting of a possession suffix and an agreement marker coindexed with the possessor. This is particularly clear in case of a plural possessum, where the possession suffix and the agreement marker are separated by a plural suffix, as shown in (4). If the possessum is singular, the possession suffix and the agreement marker are represented by a single portmanteau morpheme in some cases.

$\begin{array}{lllll}\text { az én } & \text { kalap-ja }-\mathrm{i}-\mathrm{m} & \text { a } & \text { mi kalap-ja }-\mathrm{i}-\mathrm{nk} \\ \text { the I } & \text { hat }- \text { POSS-PL-1SG } & \text { the we } & \text { hat }- \text { POSS-PL-1PL }\end{array}$

$\begin{array}{ll}\text { a te kalap-ja -i -d } & \text { a ti kalap-ja -i -tok } \\ \text { the you hat -POSS-PL-2SG } & \text { the you hat -POSS-PL-3PL } \\ \text { az ö kalap-ja -i -0 } & \text { az ö(k) kalap-ja -i -k } \\ \text { the he hat -POSS-PL-3SG } & \text { the they hat -POSS-PL-3PL }\end{array}$


Bartos (2000) modified Melcsuk's theory in an important respect: he observed that in the case of a lexical possessor, the agreement suffix is absent. Whereas a 3rd person plural pronominal possessor elicits - in addition to the -ja possession suffix - a - $k$ agreement marker, a 3rd person plural lexical possessor only allows the presence of the possession suffix:
az ö(k) kalap -ja $-\mathrm{i} \quad-\mathrm{k}$
a fiúk kalap -ja -i
the they hat -POSS -PL -3PL
the boys hat -POSS -PL

Although the presence or absence of the zero 3rd person singular agreement suffix is harder to point out, Bartos (2000: 678) managed to show its absence in the case of a lexical possessor. His argument is based on the minimal pair in (6):

(6)a.??Ez itt a Péter és az én ház-am.

this here the Peter and the I house-POSs.1SG

'This is Peter's and my house.'

b. * Ez itt az ő és az én ház-am.

this here the he and the I house-POSS.1SG

'This is his and my house.'

Whereas (6b), involving the coordination of two pronominal possessors of different persons, is ungrammatical, (6a), involving the coordination of a lexical and a pronominal possessor, is merely marginal. Bartos derives the ungrammaticality of (6b) from the fact that házam 'house-POSS.1SG' cannot agree simultaneously with a third person singular and a first person singular pronoun. (6a) involves a lesser conflict: of the two coordinated possessors, only the pronominal possessor elicits agreement; the lexical possessor only requires the presence of the possession morpheme on the possessum.

Relying on Bartos's observation, den Dikken (1999) explained a further fact related to dative marked possessors. Namely, whereas a dative possessor internal to the projection of the possessum elicits a possession suffix without the agreement morpheme on the possessum (7), an external lexical possessor can optionally also elicit an agreement marker (8a,b). Den Dikken derived this fact from the assumption that in the presence of an agreement marker, the 
possessor agrees with a dropped internal pronominal possessor, as shown in (8b). The lexical possessor is in left dislocation, generated in situ.

(7) A fiúk-nak a kalap-ja/*kalap-ju-k elveszett.

the boys-DAT the hat-POSS/ hat-POSS-3PL got.lost

'The boys' hats got lost.'

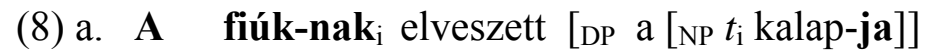

the boys-DAT got.lost the hat-POSS

b. A fiúk-nak $k_{\mathrm{i}}$ elveszett [DP a [NP pro $_{\mathrm{i}}$ kalap-j-uk $\left.\left.\mathbf{k}_{\mathrm{i}}\right]\right]^{2}$

the boys-DAT got.lost the hat-POSS-3PL

Assuming the analyses in $(8 \mathrm{a}, \mathrm{b})$, the presence vs. absence of agreement on the possessum of an external possessor can be used as evidence of whether the possessor has been generated outside the maximal projection of the possessum, binding an internal pronominal possessor, or it has been generated internally, and has been externalized via movement.

\section{External possessors across languages}

External possessors are attested in languages of different families in all parts of the globe. Payne \& Barshi (1999) formulate their defining properties as follows: (i) The possessor is coded as a core grammatical relation (e.g., a subject, object, or dative) of the verb, or - as reported about Tzotzil by Aissen (1979) - it is coded as a structural topic; (ii) it is coded in a constituent separate from that containing the possessum; (iii) it is not licensed by the core argument frame of the verb. External possessors are derived by possessor raising, or by possessum incorporation, or by adding an affected participant to the theta-grid of the verb.

The properties of European external possessors have been described by Haspelmath (1999). In a cluster of languages restricted to central and southern Europe, including German, Romance, Slavic, and the Balkan languages, they bear dative case. They are claimed to be

\footnotetext{
${ }^{2}$ Notice that the $-k$ suffix on the possessum marks the plurality of the possessor. The fact that single hats of multiple possessors yield a plurality of hats is not marked by a plural suffix in standard Hungarian, unlike in English. Thus (7) is underspecified: it can denote a single hat collectively owned by a group of boys, or single hats owned by each one of a group of boys.
} 
subject to a strict affectedness condition: the possessor can only be realized externally if it is thought to be mentally affected by the situation.

Haspelmath claims that the licensing conditions of European external possessors form implicational hierarchies. The higher a possessor is in the animacy hierarchy in (9), the more likely it is to be externalized. More precisely, if a language allows an element in the implicational hierarchy in (9) as an external possessor, it will also allow every element preceding it in the hierarchy.

(9) Animacy Hierarchy

1st $/ 2$ nd pers. $>$ 3rd pers. $>$ proper name $>$ other animate $>$ inanimate

Possessor externalization is most likely to occur in sentences whose predicate describes a situation that affects the patient, i.e.:

(10) Situation Hierarchy

patient affecting $>$ dynamic non-affecting $>$ stative

The ease of possessor externalization also depends on the relation between the possessor and the possessum:

(11) Inalienability Hierarchy

body part $>$ garment $>$ other contextually unique item

The grammatical function of the possessum also affects the externalizability of the possessor. According to Haspelmath, it is most common in the case of goal PPs, i.e.:

(12) Syntactic Relations Hierarchy

$\mathrm{PP}>\mathrm{DO}>$ unaccusative subject $>$ unergative subject $>$ transitive subject

Nikolaeva (2002) claims that the dative possessor construction appeared in Hungarian as a result of convergence with European languages. Hungarian may have inherited the possibility of possessor externalization from Proto-Ugric and Proto-Uralic (as Ob-Ugric and Samoyedic languages also have external possessors), however, the dative marking of the external possessor must be due to contacts with neighboring Indo-European languages. 
This paper will show that Hungarian external possessors represent three different types of the external possessors attested across languages: Hungarian has (i) external possessors derived by the introduction of an affected participant coindexed with the pro possessor of a coargument, (ii) external possessors derived by the topicalization, focusing, or Q-raising of an internal possessor, and (iii) external possessors arising owing to possessum incorporation. The discussion below will show that the three types have different properties, and different licensing conditions involving different subsets of the above set of implicational hierarchies.

\section{Thematically licensed external possessors}

In Hungarian sentences of type (13a), the dative-marked constituent co-occurs with a theme argument bearing possessive inflection, and is interpreted as the external possessor of the theme. However, as shown in (13b), the dative marked constituent can also co-occur with a theme which has a non-coreferent possessor, or has no possessor at all - as pointed out by Rákosi (2006: 91). This fact suggests that the dative constituent and the possessor of the theme in (13a) can be independently licensed, and their referental identity is a consequence of a binding relation between them.

(13)a. János-nak $\mathrm{k}_{\mathrm{i}}$ fáj a pro $_{\mathrm{i}}$ fej-e John-DAT hurts the head-POSS.3SG 'His ${ }_{\mathrm{i}}$ head hurts $\mathrm{John}_{\mathrm{i}}$.'

b. János-nak $\mathrm{k}_{\mathrm{i}}$ fáj a pro $_{\mathrm{i} / \mathrm{j}}$ kudarc-a /Péter kudarc-a /a kudarc. John-DAT hurts the failure-POSS.3SG/Peter failure-POSS /the failure 'His $\mathrm{i}_{\mathrm{i} j}$ failure/the failure hurts $\mathrm{John}_{\mathrm{i}}$.'

This type of dative constituent is obligatorily interpreted as the external possessor of the theme if the possessum is its inalienable property, as in (13a) and (14a). The more alienable the possessum is, the easier it is to interpret the experiencer and the possessor to be disjoint in reference, as demonstrated by (14b) and (14c).

(14)a. János-nak $\mathrm{i}_{\mathrm{i}}$ hiányzik egy pro $_{\mathrm{i}}$ fog-a.

John-DAT misses a tooth-POSS.3SG

' John ${ }_{\mathrm{i}}$ is missing a tooth of his ${ }_{\mathrm{i}}$.' 
b. János-nak $k_{i}$ hiányzik a pro $_{\text {//?j }}$ gyürü-je.

John-DAT misses the ring-POSS.3SG

'John $n_{\mathrm{i}}$ is missing his $\mathrm{i}_{\mathrm{i} / \mathrm{j}} / \mathrm{her}_{\mathrm{j}}$ ring.'

c. Jánosnak $k_{\mathrm{i}}$ hiányzik a pro $\mathrm{p}_{\mathrm{i}, \mathrm{j}}$ társaság-a /a társaság.

John-DAT misses his company-POSs.3sG/the company

'John ${ }_{i}$ is missing his ${ }_{i}$ company (of friends)/his ${ }_{j}$ company/the company., ${ }^{3}$

A dative marked affected locative behaves in a similar way: if the theme is an inalienable possession of the locative, the locative obligatorily binds the pro possessor of the theme; however, if the possession is alienable, their disjoint reference is also possible:

(15)a. János-nak $\mathrm{i}_{\mathrm{i}}$ meg-van $\operatorname{pro}_{\mathrm{i}}$ minden fog-a $/ \mathrm{az}_{\mathrm{a}}$ pro $_{\mathrm{i} /{ }_{\mathrm{j}}}$ állás-a John-DAT PRT is every tooth-POSS.3SG/the pro job-POSS.3SG 'John ${ }_{\mathrm{i}}$ has got all his teeth/his $_{\mathrm{i}, \mathrm{j}}$ job.'

b. János-nak $k_{\mathrm{i}}$ meg-van a pro $\mathrm{i}_{\mathrm{j}, \mathrm{j}}$ könyv-e /a könyv John- DAT PRT is the job-POSS.3SG/the book 'John ${ }_{\mathrm{i}}$ has got his $\mathrm{i}_{\mathrm{i}, \mathrm{j}}$ book/the book.'

The fact that the dative marked constituent of this sentence type is not necessarily coreferent with the possessor of the theme argument unless there is an inalienable relation between them is evidence that the dative constituent is (or, at least, can be) generated independently of the theme, external to its maximal projection, where it is assigned an 'affected' theta role by the verb. The constituent assigned the possessor role by the possessed theme is a pro.

Nevertheless, the 'affected' theta role is not part of the core theta grid of the verb, as it can be absent, and the affected participant can also appear as a caseless or dative internal possessor:

(16)a. Fáj a János fej-e.

\footnotetext{
${ }^{3}$ The possessor of the theme can also be a dative-marked internal possessor - see Rákosi (2006: 91), e.g.:

(i) Jánosnak $k_{\mathrm{i}}$ hiányzik Mari-nak a társaság-a .

John-DAT misses Mary- DAT the company-POSS

'John ${ }_{\mathrm{i}}$ is missing Mary's company.'
} 
hurts the John head-POSS

'John's head hurts.'

b. Meg-van Mari-nak a gyerek-e.

PRT is Mary-DAT the child-POSS

'Mary's child has been born.'

Recall that a lexical possessor and a pronominal possessor elicit different inflections on the possessum; a pronominal possessor also triggers agreement in addition to the possession suffix. Hence if the proposed analysis of (13)-(15) is correct, and their dative constituent is, indeed, generated externally, and the internal possessor is a pro-dropped pronominal coindexed with it, then speakers prefer agreement on the possessum. However, as the assignment of the affected theta role by verbs like fáj 'hurts', hiányzik 'is missing', megvan 'is present' is never obligatory, generating the dative constituent as an internal possessor and externalizing it by movement is also predicted to be an option. In this case, the possessum bears possessive inflection without agreement.

These predictions have been tested against the judgements of 33 Hungarian native speakers. They were presented a questionnaire containing the external possessor constructions to be discussed in this paper in a randomized order (with no fillers inbetween). Each sentence was provided in two versions: with and without agreement on the possessum. The informants had to mark their preferred options. ${ }^{4}$ The test sentences included the minimal pairs in (17)-(19). The (a) sentences are the agreeing versions, involving a pro possessor coindexed with the dative noun phrase. The (b) sentences are the non-agreeing versions, containing a trace in the position of the internal possessor.

(17)a. A fiúk-nak fáj a pro fej-ü-k. the boys-DAT hurts the head-POSS-3PL 'The boys' heads hurt.'

b. A fiúk-nak fáj a $t$ fej-e. the boys-DAT hurts the the head-POSS

\footnotetext{
${ }^{4}$ In fact, 40 participants filled in the questionnaire, however, 7 were disregarded because they gave identical answers in all conditions: 4 subjects chose the agreeing version in each case, whereas 3 subjects chose the nonagreeing version in each case. I concluded that their grammars lack one of the two structural options, hence their answers cannot be used for the distinction of the two possible derivations.
} 
'The boys' heads hurt.'

(18)a. A fiúk-nak hiányzanak a pro bölcsességfog-a-i-k.

the boys- DAT miss the wisdom.teeth-POSS-PL-3PL ${ }^{5}$

'The boys' wisdom teeth are missing.'

b. A fiúk-nak hiányzanak a $t$ bölcsességfog-a-i.

the boys-DAT miss.3PL the wisdom.tooth-POSS-PL

'The boys' wisdom teeth are missing.'

(19)a. A másodévesek-nek még nincs meg a pro szakdolgozat-u-k.

the sophomores-DAT still isn't PRT the thesis-POSS-3PL

'The sophomores still don't have their theses.'

b. A másodévesek-nek még nincs meg a $t$ szakdolgozat-a.

the sophomores-DAT still isn't PRT the thesis-POSS

'The sophomores still don't have their theses.'

The 33 participants preferred the agreeing versions of the minimal pairs in (17)-(19) in the

following proportions:

The number and percentage of those preferring the agreeing possessum:

(17a): $23 \quad 70 \%$

(18a): $28 \quad 85 \%$

(19a): $29 \quad 88 \%$

The results confirm that if a verb can license a dative marked affected constituent interpretable as the external possessor of its theme argument, speakers tend to interpret the dative constituent as a base-generated affected complement of the verb, and relate it to the dropped pronominal possessor of the theme via binding.

\footnotetext{
${ }^{5}$ Recall that the $-i$ - plural suffix denotes the plurality of the possessum, whereas - $k$ marks the plurality of the possessor. The plurality of the posessum means in literary Hungarian that every possessor has more than one instance of the possessum. In everyday usage the $-i$ - plural suffix can also be used if the possessors collectively own more than one instance of the possessum.
} 
Intuitively, the dative constituent of the following sentences also represents an affected (malefactive or benefactive) participant of the event. However, the verbs of these sentences cannot license an affected participant independently of the theme; the referential identity of the affected participant and the possessor of the theme is obligatory. In the case of (20a), this may be due to the inalienable relation between the theme and the affected participant of the megoperál 'operate on'. A similar obligatory part-whole relation holds between the dative constituent and the theme in the case of verbs like kilyukad, leszakad, elromlik, as well (see 20b). The verb ellop 'steal' does allow an independently licensed malefactive participant; however, it is in the ablative case (see 21b).

(20)a. Megoperálták János-nak tegnap a fül-é-t. operated.they John-DAT yesterday the ear-POSS-ACC 'John's ear was operated on yesterday.'

b. Kilyukadt a bicikli-nek tegnap a kerek-e. got.punctured the bike-DAT yesterday the wheel-POSS 'The bike's wheel got punctured yesterday.'

(21)a. Ellopták János-nak a villamoson a pénztárcá-já-t. stole.they John-DAT the tram.on the purse-POSS-ACC 'John's purse was stolen on the tram.'

cf.

b. Ellopták János-tól $l_{i}$ a villamoson $\left[\right.$ pro $_{\mathrm{i} / \mathrm{j}}$ a pénztárcá-já-t $]$. stole.they John-ABL the tram.on the purse-POSS-3SG-ACC 'His purse was stolen from John on the tram.'

Since the -nak/nek marked constituent of these sentences cannot be a complement of the verbal predicate, it must be the extracted possessor of the theme, adjoined to the VP. If this conclusion is correct, then we expect speakers to supply the possessum with a possession suffix including no agreement marker. This prediction has been verified in the questionnaire by the minimal pairs in (22)-(24).

(22)a. Kihúzták a fiúk-nak tegnap a pro fog-u-k-at pulled.they the boys-DAT yesterday the tooth-POSS-3PL-ACC 
'The boys' teeth were pulled out/the boys had their teeth pulled out yesterday.'

b. Kihúzták a fiúk-nak tegnap a $t$ fog-á-t.

pulled.they the boys- DAT yesterday the tooth-POSS-ACC

'The boys' teeth were pulled out/the boys had their teeth pulled out yesterday.'

(23)a. Kilyukadt a biciklik-nek tegnap a pro kerek-ü-k.

got.punctured the bicycles-DAT yesterday the wheel-POSS-3PL

'The bikes' wheels got punctured yesterday.'

b. Kilyukadt a biciklik-nek tegnap a $t$ kerek-e.

got.punctured the bicycles-DAT yesterday the wheel-POSS

'The bikes' wheels got punctured yesterday'

(24)a. Ellopták a fiúk-nak a villamoson a pro pénztárcá-ju-k-at.

stole.they the boys-DAT the train-on the purse-POSS-3PL-ACC

'The boys' purses were stolen on the tram.'

b. Ellopták a fiúk-nak a villamoson a $t$ pénztárcá-já-t.

stole.they the boys-DAT the train-on the purse-POSS-ACC

'The boys' purses were stolen on the tram.'

The number and percentage of those preferring the non-agreeing possessum:

(22) $24 \quad 73 \%$

(23) $24 \quad 73 \%$

(24) $15 \quad 45 \%$

The prediction following from the hypothesized derivation has been partially satisfied: the great majority of speakers preferred the non-agreeing version derived by possessor extraction in the case of examples (22) and (23); but only less than half of them preferred it in the case of example (24). Apparently, some speakers (27\%) interpret an external possessor affected by an event as a complement of the verb denoting the given event also in case the verb cannot license a dative complement on its own. The acceptance rate is higher (55\%) if the verb selects an affected argument but marks it by a case other than dative. This is the case with 
example (24), where the verb ellop 'steal' can select an affected complement in the ablative case.

Though the dative marked constituents in examples (22) and (23) originate in the projection of the possessum for the majority of speakers, their externalization is subject to the same conditions as the base-generation of an affected argument. Thus a possessor that is not affected cannot be externalized. (25) and (26) below describe events which usually do not affect the possessor, hence the use of an external possessor is inappropriate; the sentences are marginal.

(25)?? Találkoztam a fiúk-nak a versenyen a szül-e-i-k-kel. met.I the boys-DAT the race.on the parent-POSS-PL-3PL-INS 'I met with the boys' parents at the race.'

(26)?? Láttam a fiúk-nak a versenyen a szül-e-i-k-et. saw-I the boys-DAT the race.on the parent-POSS-PL-3PL-ACC 'I saw the boys' parents at the race.'

The Inalienability Hierarchy also plays a role in the licensing of this type of external possessors, as shown by the degraded acceptability of (27c) as compared to (27a,b). In (27c), the affectedness off the possessor is also very mild.

(27)a. Megsérült a fiúk-nak a meccsen a láb-u-k was.hurt the boys-DAT the match.on the leg-POSS-3PL 'The boys' legs got hurt at the match.'

b. Elveszett a fiúk-nak a kiránduláson a sapká-ju-k. got.lost the boys-DAT the excursion.on the hat-POSS-3PL 'The boys' hats got lost on the excursion.'

c.? Átvilágították a vendégek-nek a bejáratnál a csomag-ja-i-k-at. $\mathrm{X}$-rayed.they the guests-DAT the entrance.at the bag-POSS-PL-3PL-ACC 'They X-rayed the guests' bags at the entrance.' 
A dative marked constituent with an affected theta role can only bind the possessor of the theme (a direct or prepositional object, or an unaccusative subject); the possessor of the subject of a transitive verb cannot be realized as an external possessor of this type, which indicates that a version of the Syntactic Relations Hierarchy is in effect. Cf.

(28)a. Kihívta [a fiúk-nak a szomszéd-ja] a rendőrséget. called the boys-DAT the neighbour-POSS the police.ACC 'The boys' neighbour called the police."

b. *Kihívta a fiúk-nak a rendőrséget a szomszéd-ju-k. called the boys-DAT the police.ACC the neighbour-POSS-3PL

As for the Animacy Hierarchy, most external possessors interpreted as affected arguments or adjuncts are animate; however, in sentences describing the violation of the integrity of an object, involving verbs like kilyukad 'be punctured', elromlik 'go wrong', letörik 'break off', leszakad 'tear off', the external possessor can also be inanimate:

(29)a. Könnyen leszakad a fül-ü-k az ilyen táskák-nak. easily off-comes the handle-POSS-3PL the such bags-DAT 'The handles of such bags come off easily.'

b. Tönkrement a számítógép-nek tegnap a merevlemez-e. got.damaged the computer-DAT yesterday the hard-disk-POSS 'The hard disk of the computer got damaged yesterday.'

In sum: if the theme argument of the verb undergoes a change that also affects its possessor, the possessor can be realized as a clause level affected constituent, assigned a theta role by the verb, or licensed as a VP-adjunct. If the affected constituent is licensed by the verb, it can be related to the possessum as the binder of its dropped pronominal internal possessor. The external possessor interpretation of a clause-level dative constituent is possible if it is affected, and if the possessum is an object or an unaccusative subject. The typical affected constituent is animate. The inalienability of the possessum makes the external possessor interpretation of the dative constituent obligatory.

\section{External possessors licensed as clause-level operators}


In Tzotzil, a Mayan language, whose sentence structure is similar to that of Hungarian, with a preverbal focus slot and a pre-focus topic position in the left periphery, a possessor can be extracted into topic position - see Aissen (1979). (As Aissen observed, English needs the verb have because in English a possessor can only be topicalized if it is a grammatical subject.) The Hungarian possessor extraction operation analyzed by Szabolcsi (1983), claimed to be motivated by the need for the possessor to assume an operator role and to occupy a scope position, is also of the Tzotzil type. A possessor in Hungarian can undergo not only topicalization, but, alternatively, also focusing and quantifier raising. For example:

\section{Possessor topicalization:}
A bicská-nak
akár zárat
is lehet
szerelni $\left[t_{\mathrm{i}}\right.$ the pocket-knife-DAT even lock.ACC also possible fix.INF the point-POSS-with 'The pocket knife one can even fix a lock with the point of. [The pocket knife is such that one can even fix a lock with its point.]'

\section{Possessor focusing:}

(31) Csa
Csak a SVÁJCI BICSKÁ-NAK $\mathrm{i}_{\mathrm{i}}$ lehet $\left[t_{\mathrm{i}}\right.$ a hegy-é-vel $]$ zárat szerelni. only the Swiss pocket-knife-DAT possible the point-POSS-with lock.ACC fix.INF 'It is only the Swiss pocket knife that one can fix a lock with the point of.'

\section{Possessor Q-raising:}

(32)
Minden svájci bicská-nak ${ }_{i}$
zárat
lehet
szerelni $\left[t_{\mathrm{i}}\right.$ a
every Swiss pocket-knife-DAT lock.ACC possible fix.INF the point-POSS-with 'One can fix a lock with the point of every Swiss pocket knife.'

The licensing conditions of these types of external possession constructions are different from those presenting the dative possessor as an affected participant of the given event. The topicalized, focused and Q-raised possessor must satisfy the conditions of topicalization, focusing, and Q-raising, respectively. Thus, possessor topicalization is only acceptable if it creates a meaningful predication relation between the possessor and the rest of the sentence. This condition is satisfied in (30), which predicates a property of the possessor, but is not satisfied in (33):

(33)?*A bicská-nak $k_{\mathrm{i}} \quad$ megszereltem a zárat [a $t_{\mathrm{i}}$ hegy-é-vel]. 
the pocket-knife-DAT fixed.I the lock.ACC the point-POSS-with

'The pocket knife, I fixed the lock with the point of.'

A possessor can be focused in Hungarian if it can be interpreted as an identificational predicate; and a possessor can only be Q-raised into a position c-commanding the rest of the clause if it is able to take scope over the proposition. These conditions are satisfied in (31) and (32), respectively, as is shown by their paraphrases:

(31') 'What one can fix a lock with the point of is the Swiss pocket knife.'

(32') 'It is true for every Swiss pocket knife that one can fix a lock with its point.'

Since these types of dative constituents are assigned a possessor theta role inside the maximal projection of the possessum (cf. Szabolcsi 1994: 193-194), and are externalized by A-bar movement, they are expected to elicit possessive inflection without agreement. The results of our questionnaire mostly bear out this prediction; nevertheless, a minority of speakers prefer agreement on the possessum in this case, as well:

(34)a. A laptopok-nak $k_{\mathrm{i}}$ le-ment az pró ár-u-k. the laptops-DAT down-went the price-POSS-3PL 'The price of laptops has fallen.'

b. A laptopok-nak $k_{\mathrm{i}}$ le-ment $t_{\mathrm{i}}$ az ár-a. the laptops-DAT down-went the price-POSS 'The price of laptops has fallen.'

(35)a. Az autók-nak ${ }_{\mathrm{i}}$ kicserélték a pro motor-ju-k-at. the cars-DAT replaced.they the motor-POSS-3PL-ACC 'The cars' motors were replaced.'

b. Az autók-nak kicserélték $t_{\mathrm{i}}$ a motor-já-t. the cars-DAT replaced-they the motor-POSS-ACC 'The cars' motors were replaced.' 
(34) $22 \quad 67 \%$

(35) $28 \quad 85 \%$

The great majority of speakers chose possessive inflection without agreement, elicited by the A-bar moved lexical possessor. The minority of speakers who opted for the agreeing version, may have done so for one or more of the following reasons: (i) Hungarian prescriptive grammars prescribe agreement between a possessor and its possessum if they are not adjacent (Grétsy and Kovalovszky 1980: 349). (ii) The inalienability of the possessum, and/or the affectedness of the possessor may license the interpretation of the possessor as an affected adjunct also in the case of topicalized and focussed possessors. (iii) Den Dikken (1999) suggests that a possessor in the left periphery may be analyzed as a constituent in left dislocation, binding an empty pronominal possessor. As a pronominal possessor is always dropped unless it is set into a contrast, this possibility cannot be excluded.

Notice that the constraints attributed to external possessor constructions across languages need not be observed in these cases. Thus the extracted possessor need not be animate, as illustrated by examples (30)-(32) and (34)-(35). The extracted possessor need not be an affected participant of the given event:

(36) A fiúk-nak tegnap láttam az any-já-t lany-ju-k-at. the boys-DAT yesterday saw.I the mother-POSS-ACC/mother-POSS-3PL-ACC 'The boys, I saw the mother of yesterday.'

The alienability of the possessum does not seem to diminish the acceptability of possessor extraction:

(37) Az utasok-nak a repülőtéren átvilágítják a csomag-já-t /csomag-ju-k-at. the passengers-DAT the airport.on X-ray.they the bag-POSS-ACC/bag-POSS-3PL-ACC 'The passengers have their bags X-rayed at the airport.'

At the same time, the possessor of the agent of a transitive $\mathrm{V}$ is difficult to externalize:

(38) ?A gyerek-nek $k_{\mathrm{i}}$ tegnap fel kereste [ $t_{\mathrm{i}}$ az any-ja] az osztályfönököt the child-DAT yesterday PRT visited the mother-POSS the form-master.ACC 'Yesterday, the child's mother visited the form master.' 
The fact that the possessor of an agent subject cannot be extracted in most languages is derived from the fact that the agent, the initiator of the event, is typically not affected by the event, hence its possessor cannot be an affected party, either, even if there is an inalienable relation between them. However, if affectedness plays no role in the licensing of this type of possessor extraction, then the impossibility of possessor extraction from the agent must have a different reason. Notice that the possessor of the agent can, in fact, be extracted if the agent is focussed:

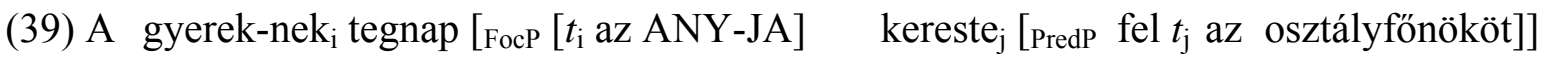
the child-DAT yesterday the mother-POSS visited PRT the form-master.ACC 'It was the child's mother who visited the form master yesterday.'

This array of facts can be explained along the following lines: a possessor is topicalized without its possessum if the possessum is [new] and the possessor is [given]. Whereas an object or intransitive subject possessum can be [new] whether it is narrow focus in Spec,FocP or part of an in situ VP-focus, a transitive subject is typically [new] only if it is narrow focus moved to Spec,FocP.

In sum: A possessor can be externalized via topicalization, focusing, or quantifier-raising if it satisfies the conditions of these operations. Possessor externalization via A-bar movement is not subject to the implicational hierarchies constraining the use of thematically licensed external possessors.

\section{External possessors licensed by possessum incorporation}

As Szabolcsi (1986, 1992) demonstrated, an internal possessor makes a noun phrase [+definite]. Hungarian displays differential object-verb agreement; the verb agrees with its object if it is definite. An object represented by a possessive construction elicits the definite conjugation, even if both the possessor and the possessum have indefinite determiners:

(40) Csak egy angol költő néhány vers-é-t olvas-t-uk /*olvas-t-unk. only an English poet few poem-POSS-ACC read-PAST-DEF.1PL/read-PAST-INDEF.1PL 'We have only read a few poems of an English poet.' 
A seminal observation of Szabolcsi (1986) has been that verbs of existence and coming into being require a [-specific] indefinite internal argument. If their internal argument has a possessor, it must be externalized, as an external possessor does not necessarily make its possessum definite. $\mathrm{Cf}$.

(41)a.*Van Mari pénz-e.

is $\quad$ Mary money-POSS

'Mary has money.' b. Mari-nak $k_{i}$ van $t_{i}$ pénz-e. Mary-DAT is money- POSS

'Mary has money.'

(42)a.*Tegnap Mari gyerek-e született. yesterday Mary child-POSs was.born 'Yesterday Mary's child was born.'

b. Mari-nak $\mathrm{i}_{\mathrm{i}}$ tegnap $t_{\mathrm{i}}$ gyerek-e született. Mary-DAT yesterday child-POSS was.born 'Yesterday Mary had a child (born).'

Szabolcsi (1986) claims that in sentences of this type, the possessum is semantically incorporated into the $\mathrm{V}$. The verb and the posessum form a 'lexical integer', as they assign theta roles together, and no theta role assignment takes place between them. Their semantic relation can be looser or closer, lexicalized, or established in the course of the derivation. In syntax, they enter into the „closest possible” relationship, which means a verb modifier - verb relation, analyzed as a sister relation under V' in 1986, and as a specifier-head relation in a PredP projection in more recent frameworks (e.g., Koster 1994, É. Kiss 2006).

(43) Vég-e van az előadás-nak. end-POSS is the show-DAT 'The show has ended.'

(44) A vállalat-nak /Mari-nak jó /rossz hír-e van. the company-DAT/Mary-DAT good/bad reputation-POSS is 'The company/Mary has a good/bad reputation.' 
Although the possessor of such an incorporated, non-specific indefinite noun phrase is external to the possessum, the possessum bears possessive inflection, including an agreement morpheme in the case of a pronominal possessor:

(45) (Nekem) van gyerek-em.

I.DAT is child-POSS.1SG

'I have a child.'

(Neked) van gyereked.

you.DAT is child-POSS.2SG

(Neki) van gyerek-e.

she.DAT is child-POSS.3SG
(Nekünk) van gyerek-ünk.

we.DAT is child-POSS.1PL

'We have a child.'

(Nektek) van gyerek-etek.

you.DAT is child-POSS.2PL

(Nekik) van gyerek-ük.

they.DAT is child-POSS.3PL

The agreement on the possessum suggests that the possessor has been generated in the projection of the possessum, and has been externalized after agreement has taken place. Assuming the noun phrase theory of Bartos (2000) (based on Zamparelli (2000)), according to which definite noun phrases are DPs whereas indefinite noun phrases are NumPs, verbs of existence and coming into being subcategorize for a NumP or a bare NP complement. Since they do not tolerate a DP, the dative possessor of their complement must be removed, and it must be adjoined to the VP. (A caseless possessor cannot survive as a clause-level complement.)

If a lexical possessor is extracted, the possessum is predicted to bear possessive inflection without agreement. This prediction has also been tested. Speakers had to choose the preferred version of the following minimal pairs:

(46)a. Fél hatkor vég-ü-k van az egyetemi órák-nak.

half six.at end-POSS-PL is the university classes-DAT

'The university classes end at half past five.'

b. Fél hatkor vég-e van az egyetemi órák-nak. half six.at end-POSS is the university classes-DAT 'The university classes end at half past five.'

(47)a. Ikr-e-i-k születtek Szabó-ék-nak! twin-POSS-PL-3PL were.born Szabó-PL-DAT 
'Twins have been born to the Szabós!'

b. Ikr-e-i születtek Szabó-ék-nak! twin-POSS-PL were.born Szabó-PL-DAT 'Twins have been born to the Szabós!'

(48)a. Az egyetemisták-nak nincs pénz-ü-k. the students-DAT isn't money-POSS-3PL

'Students have no money.'

b. Az egyetemisták-nak nincs pénz-e. the students-DAT isn't money-POSS 'Students have no money.'

The number and percentage of those preferring the agreeing possessum:

(46) $13 \quad 33 \%$

(47) $3194 \%$

(48) $28 \quad 85 \%$

In the case of (46), the majority of speakers preferred the non-agreeing possessum, as predicted. However, in the other two cases, nearly all subjects chose the agreeing variant. The relevant difference between (46) and (47)-(48) appears to be that in (46) the possessor is inanimate, not affected by the event, whereas in (47)-(48), it is an animate, affected participant. This generalization has been confirmed by a follow-up test: speakers had to choose the preferred version of the following sentence pairs:

(49)a. A japán autók-nak jó hír-ü-k van. the Japanese cars-DAT good reputation-POSS-3PL is 'Japanese cars have a good reputation.'

b. A japán autók-nak jó hír-e van. the Japanese cars-DAT good reputation-POSS is 'Japanese cars have a good reputation.' 
(50)a. A japán mérnökök-nek jó hír-ü-k van.

the Japanese engineers-DAT good reputation-POSS-3PL is

'Japanese engineers have a good reputation.'

b. A japán mérnökök-nek jó hír-e van.

the Japanese engineers -DAT good reputation-POSS is

'Japanese engineers have a good reputation.'

$75 \%$ of the 20 subjects tested chose different inflectional morphology in the two minimal pairs, and all of those opting for different inflections chose possessive inflection without agreement in the case of the inanimate possessor in (49), and possessive inflection with agreement in the case of the animate possessor in (50).

The role that animacy plays suggests that in the agreeing variant, the dative constituent is generated as an external affected participant. The 'affected' theta role is easier to assign to animate participants, that is why this derivation is the preferred option only in the case of animate possessors. This type of possessor externalization is restricted to existential sentences, where the possessum is a theme argument functioning as an unaccusative subject. That is, the animacy hierarchy, the situation hierarchy, and the grammatical relations hierarchy all seem to be in effect. Whether the possession is alienable or inalienable, on the other hand, does not seem to be crucial.

The plural agreement on the possessum in (47a), (48a), and (50a) reflects the presence of an internal pro possessor coindexed with the external possessor. Notice that a pro, representing the weak form of personal pronouns, does not necessarily render the possessum definite. Whereas a noun phrase having an overt pronominal possessor is obligatorily preceded by a definite article, and in object position obligatorily elicits definite agreement on the verb (51a), a noun phrase with a pro possessor can also have an indefinite article or no article, in which case it elicits either definite or indefinite agreement on the verb, depending on its $+/$ - specific feature (51b).

(51)a. Lát-t-uk az ő új fénykép-é-t. see-PAST-DEF-1PL the she new photo-POSS.3SG-ACC 'We have seen her new photo.'
b. Lát-t-unk
/lát-t-uk
(egy) pro új fénykép-é-t. 
'We have seen a new photo of her.'

Since a pro possessor neither acts as a definite determiner for the possessum, nor needs to be preceded by a definite determiner, its presence in the projection of the possessum does not necessitate the projection of a DP.

In sum: in sentences expressing existence and coming into being, the externalization of the possessor of the subject is a syntactic necessity, required by the need of the subject to be a non-specific indefinite noun phrase semantically incorporated into the verb. The dative internal possessor can be externalized via extraction. If the possessor is an affected participant of the situation, it tends to be licensed by the complex predicate as an affected participant coindexed with a pro possessor, with the pro eliciting agreement on the possessum. A possessor represented by a phonologically empty weak pronominal does not (necessarily) make the possessum definite or specific indefinite, hence it does not prevent the possessum from undergoing semantic incorporation.

\section{Conclusion:}

This paper has shown that a dative marked external possessor in Hungarian can be licensed in three different ways. It can be licensed thematically, as an affected participant of the event. It can be generated externally, and be assigned an 'affected' theta role by the verbal predicate. The referential identity of the dative marked affected participant and the pro-dropped internal possessor is due to a binding relation between them. Alternatively, the affected participant can also be extracted from the projection of the possessum, and be reinterpreted as an affected adjunct. The coindexing of the affected argument or adjunct and the empty element in the position of the internal possessor is facilitated if the possessor is high in the animacy hierarchy, and if the theme is an inalienable possession of the affected participant.

The external possessor can also be licensed by information structure/logical structure: a case marked possessor can assume a topic, focus, or quantifier role on its own, and can be raised into the corresponding A-bar position independently, without its possessum. For a possessor to be targeted by topic or focus movement, or by quantifier raising, it must satisfy the general conditions of the given operation.

The external possessor can also be licensed by the semantic incorporation of its possessum. The theme of a verb of existence or coming into being, to be semantically incorporated into the verb, has to be non-specific indefinite. As an overt internal possessor surfaces in the DP 
domain of its possessum, the non-specificity of the subject of a verb of existence or coming into being can only be maintained if the overt, dative marked possessor is extracted, or is generated externally as an independent clause-level constituent. An animate possessor tends to co-occur with a possessum bearing agreeing possessive inflection, which suggests that it is licensed as an affected participant binding a pro possessor. A pro acts as a weak pronoun in Hungarian, and a weak pronominal possessor functions as weak determiner, yielding a nonspecific indefinite noun phrase.

\section{References}

Aissen, Judith. 1979. Possessor ascension in Tzotzil. In L. Martin (ed.) Papers in Mayan Linguistics. Colombia, Missouri: Lucas Brothers. 89-108.

Alberti, Gábor. 1995. Role assignment in Hungarian possessive constructions. In I. Kenesei (ed.) Approaches to Hungarian 5. Szeged: JATE. 11-28.

Bartos, Huba. 2000. Az inflexiós jelenségek szintaktikai háttere [The syntactic background of inflectional phenomena]. In F. Kiefer (ed.) Strukturális magyar nyelvtan IV. Morfológia [Hungarian structural syntax IV. Morphology]. Budapest: Akadémiai Kiadó. 653-761.

Dikken, Marcel den. 1999. On the structural representation of possession and agreement. The case of (anti-)agreement in Hungarian possessed nominal phrases. In I. Kenesei (ed.) Crossing Boundaries: Theoretical Advances in Central and Eastern European Languages. Amsterdam: John Benjamins. 137-178.

É. Kiss, Katalin. 2000. The Hungarian NP is like the English NP. In G. Alberti and I. Kenesei (eds.) Approaches to Hungarian VII. Szeged: JATEPress. 119-150.

Grétsy, László and Miklós Kovalovszky. 1980. Nyelvmüvelő kézikönyv. Budapest: Akadémiai Kiadó.

Haspelmath, Martin. 1999. External possession in an European areal perspective. In D. Payne and I. Barshi (eds.) External possession. Amsterdam: John Benjamins. 109-137.

Kenesei, István. 1994. Subordinate clauses. In F. Kiefer and K. É. Kiss (eds.) The Syntactic Structure of Hungarian. Syntax and Semantics 27. New York: Academic Press. 275-354. Melcsuk, Igor. 1965. A magyar főnév birtokos személyragjainak morfológiai felépítéséről. Magyar Nyelv 61: 264-275.

Nikolaeva, Irina. (2002). The Hungarian external possessor in a European perspective. In C. Hasselblatt \& R. Blokland (eds.), Finno-Ugrians and Indo-Europeans: Linguistic and Literary Contacts. 272-285. Proceedings of the Symposium at the University of Groningen, November 22-24, 2001. Studia Fenno-Ugrica Groningana 2. Maastricht: Shaker. 
Payne, Doris and Immanuel Barshi. 1999. External Possession: What, where, how, and why. In D. Payne and I. Barshi (eds.) External possession. Amsterdam: John Benjamins. 3-29. Rákosi, György. 2006. Dative experiencer predicates in Hungarian. Utrecht: Uil-OTS.

Szabolcsi, Anna. 1983. The possessor that ran away from home. The Linguistic Review 3: 89-102.

Szabolcsi, Anna. 1992. A birtokos szerkezet és az egzisztenciális mondat [The possessive construction and the existential sentence]. Budapest: Akadémiai Kiadó.

Szabolcsi, Anna. 1994. The noun phrase. In F. Kiefer and K. É. Kiss (eds.) The Syntactic Structure of Hungarian. Syntax and Semantics 27. San Diego/New York: Academic Press. $179-274$.

Tompa, József (ed.) 1961-62. A mai magyar nyelv rendszere [The structure of present-day Hungarian]. Budapest: Akadémiai Kiadó.

Zamparelli, Roberto. 2000. Layers in the Determiner Phrase. New York: Garland. 